\title{
Damaged warship stability tests based on ANEP-77: A case study for F-110
}

\begin{abstract}
Stability tests are a core part of a hydrodynamics warship design. The acquired knowledge from the hydrodynamics model basin will affect her lifespan. Particularly, a safety assessment of damaged ships, which considers environmental conditions such as waves and wind, is critical in future operations. Over the last decade, a significant amount of experience has been gained associated with predicting the capsize behavior of intact and damaged naval vessels, and the main objective of this paper is to provide insights into different relevant physical aspects to prevent the capsizing of damaged ships in waves following the Naval Ship Code (NSC) or ANEP-77 rules. Currently, the Royal Navy of Spain is developing the future F-110 frigate class and carried out model tests at Canal de Experiencias Hidrodinámicas de El Pardo (CEHIPAR) for optimizing the forms of body hulls. Among these dynamic experiences, the most critical are the damage stability tests. Although a safety criteria of damaged ships that considers environmental conditions such as waves and wind has not yet been developed, NATO and the European maritime classification societies have developed guidelines for safety assessments such as the ANEP-77. This code contains damage scenarios and environmental conditions.
\end{abstract}

Key words: Naval Ship Code, ANEP-77, damage stability, ship safety assessment, damage scenarios, dynamic phenomena, collision, grounding, damage safety criteria, model tests.

\section{Resumen}

Las pruebas de estabilidad son una parte fundamental de un diseño de busques de guerra hidrodinámicos. El conocimiento adquirido de la cuenca del modelo hidrodinámico afectará su vida útil. En particular, una valoración de la seguridad de las naves averiadas que considera las condiciones ambientales como el oleaje y el viento, es crítico para operaciones futuras. Durante la última década, una experiencia significativa ha sido adquirida respecto de la predicción del comportamiento de la zozobra de buques militares averiados e intactos y el principal objetivo de este ensayo es dar perspectivas sobre los diferentes aspectos físicos relevantes para prevenir la zozobra de naves averiadas en olas mediante el seguimiento del Código de Buques Navales (NSC) o normas ANEP-77. Actualmente, la Armada Real de España esta desarrollando la futura clase de fragata F-110 y realizó pruebas modelo en el Canal de Experiencias Hidrodinámicas de El Pardo (CEHIPAR) para optimizar las formas de cascos de cuerpo. Entre estas experiencias dinámicas, las más críticas son las pruebas de estabilidad de averías. Aunque el criterio de seguridad de las naves averiadas que considera las condiciones ambientales tales como oleaje y viento no ha sido aún desarrollado, la OTAN y la sociedades de clasificación marítimas europeas han desarrollado guías para la evaluación de seguridad tales como la ANEP-77. Este código contiene escenarios de averías y condiciones ambientales.

Palabras claves: Código de Buques Navales, ANEP-77, estabilidad de averías, evaluación de seguridad de las naves, escenarios de daños, fenómenos dinámicos, colisión, naufragio, criterio de seguridad de averías, pruebas modelo.

Date Received: December 1 15 2016 - Fecha de recepción: Diciembre 1 de 2016

Date Accepted: December 22 2016 - Fecha de aceptación: Diciembre 22 de 2016

\footnotetext{
${ }^{1}$ Royal Navy of Spain. Madrid, Spain - Universidad Politécnica de Madrid. Madrid, Spain. Email: josemaria.riola@upm.es

${ }^{2}$ SENER. Tres Cantos, Spain - Universidad Politécnica de Madrid. Madrid, Spain. Email: rodrigo.perez.fernadez@upm.es

${ }^{3}$ ISDEFE. Madrid, Spain - Universidad Politécnica de Madrid. Madrid, Spain. Email: brodriguez@isdefe.es
} 
Fig. 1. Virtual picture F-110 Frigate class (MDEF, 2016) and ANEP-77 Edition
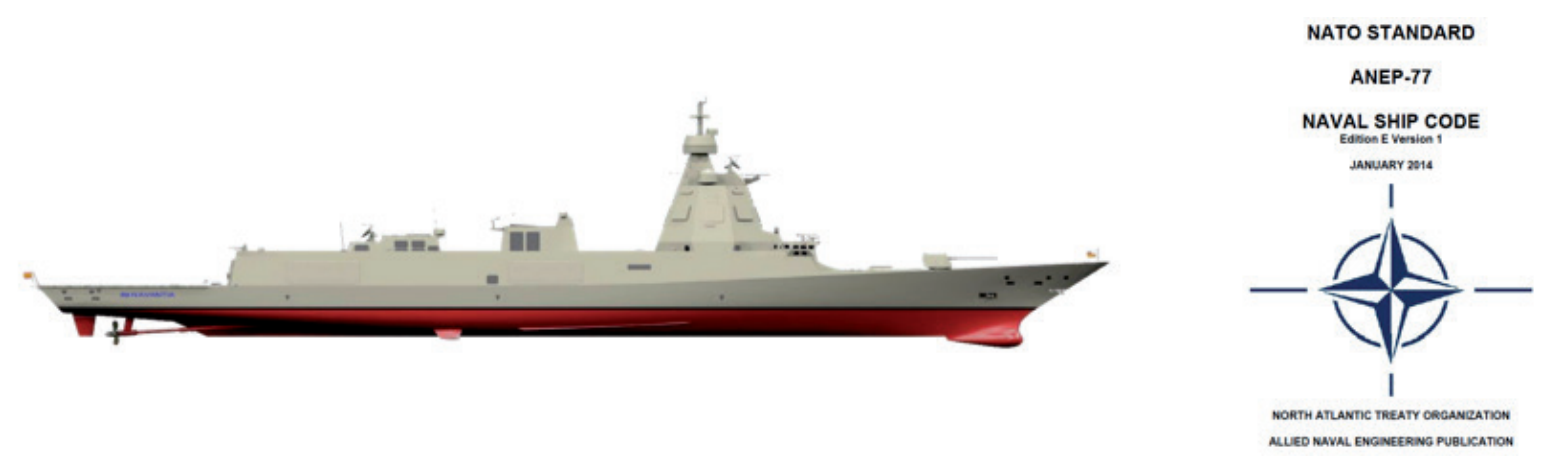

\section{Introduction}

The future F-110 frigate class is under final design definition phase and has further developed and matured the design baseline established at the end of the feasibility phase. The ship's general arrangement, propulsion machinery and key systems had been finalized, with only minor details still outstanding. In the latest interaction, the F-110 design has a length of $145 \mathrm{~m}$, a beam of $18,6 \mathrm{~m}$, a draught of $5,5 \mathrm{~m}$ and a displacement of up to 6.000Ton. Maximum speed is greater than 26kt, CODELAG propulsion machinery with a cruising speed of $17 \mathrm{kt}$ and a 4.100 nautical miles range at $15 \mathrm{kn}$. Model tests will validate the hydrodynamic and sea keeping properties of the preliminary design selected for the frigate. The Spanish Navy's requirements for the first-of-class will be available in the 2023-24 timeframe.

It is logical to think, since the sea is common for every ship, that merchant and warships are susceptible to the same type of accidents (groundings, collisions, fires, loss of stability...) and encounter the same adverse weather conditions (seafaring, fog...). On the other hand, due to the purpose for which they have been projected, warships have to deal with additional threats like hostile actions of different nature and intensity, representing all a potential risk to their stability and buoyancy.

In the United Nations Convention on the Law of the Sea (UNCLO), article twenty-nine defines a warship as "a ship belonging to the armed forces of a State bearing the external marks distinguishing such ships of its nationality, under the command of an officer duly commissioned by the government of the State and whose name appears in the appropriate service list or its equivalent, and manned by a crew which is under regular armed forces discipline." The International Convention for the Safety of Life at Sea (SOLAS), in its rule three "Chapter I - General Provisions", states that its rules do not apply to warships and ships that transport troops. So, warships are exempt from most of the laws of the merchant ships (Fig. 2), and as such, both the international and national levels have directed the safety of naval surface ships independent of statutory organizations. But there are exceptions to this; vessels can be classified and certified by Classification Societies (SC) or flag authorities and there are some aspects of the statutory legislation that warships have to consider. Thus, development of rules for warships or Naval Ship Rules by various SC is the most important contribution to work in this area.

Admitting that there is no equivalent of the International Maritime Organization (IMO) for warships, the only recognized navy specifications, Stability DDS-079-1 (Fig. 3), the North Atlantic Treaty Organization (NATO) established a decade ago some teams of specialists in the Naval Ship Classification Association (NSCA) and a partnership for classification of warships. These teams of specialists have been entrusted with the preparation of the Naval Ship Code (NSC) and a benchmark of international standards for ships. This promotes greater transparency and consistency in safety standards for warships. This code aims to fill the gap by providing the framework for armed forces security that has 
Fig. 2. Capsizing of a fishing boat in front of Libyan coast (Marina Militare Italiana, 2015)

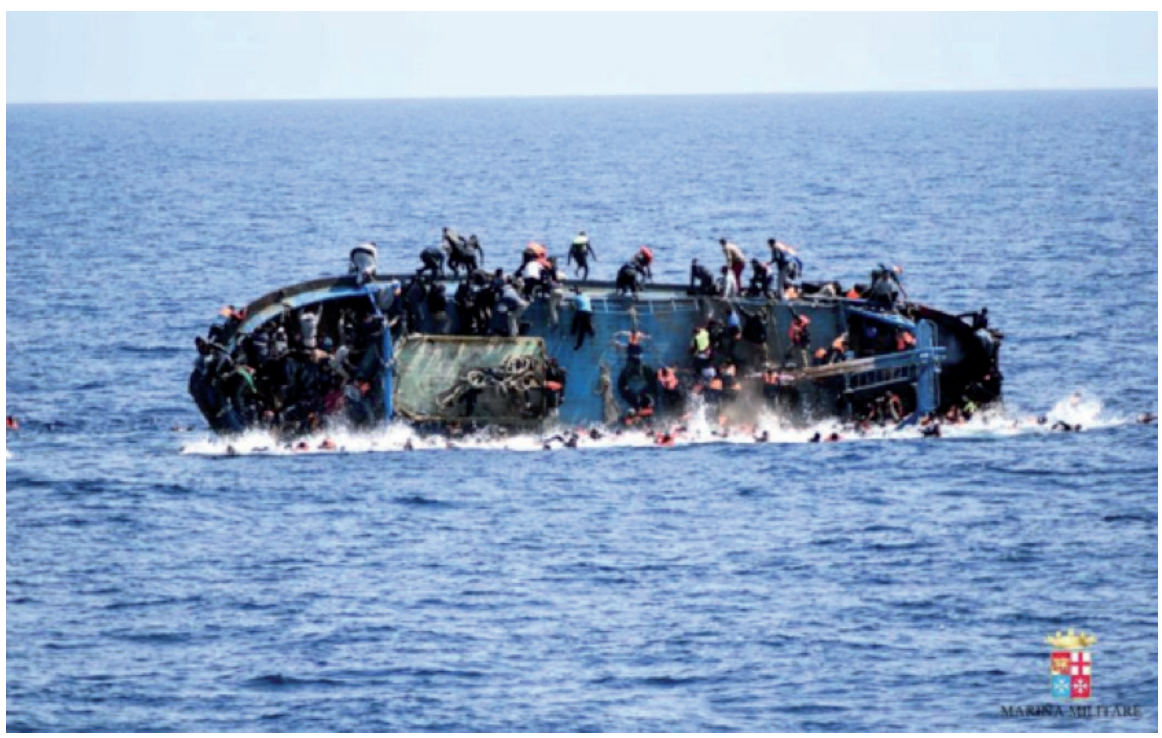

Fig. 3. Damage extension DDS-079-1 (US Navy, 1975)

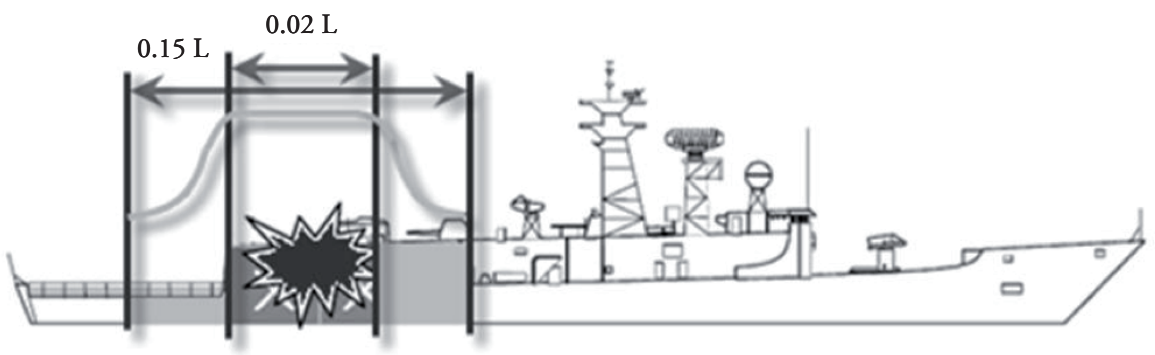

achieved acceptable levels of safety and will be the link between IMO, the Classification Societies and Navies. The development of this code provides a cost-effective framework for a naval surface ship safety management system based on and benchmarked against IMO resolutions. The specialists' teams established a goal-based approach to the development of the code, developing each chapter in turn. The Naval Authority Knowledge Management Office (NAKMO) website contains the latest version and its corresponding guide, and NATO adopts the publication as an Allied Naval Engineering Publication ANEP-77. The current version (F) was published on August 2014.

\section{Stability Requirements Evolution}

From 2009 to 2014, the evolution of some aspects of the ANEP-77 Ed. F in comparison to its 2009 edition is substantial, with a major restructuring to the Table of Contents. Chapter 3 of the ANEP-77 is titled "Buoyancy, Stability and Controllability" and has goals to provide an adequate reserve of buoyancy $(N S A, 2012)$ in all foreseeable intact and damaged conditions, an adequate stability to avoid capsizing, permit embarked persons to carry out their duties and protect the embarked persons and essential safety functions in the event of foreseeable accidents and emergencies. Therefore, the primary goal of this chapter has been set to provide the ship with the ability to remain afloat in an upright orientation in all operating conditions including loading, heavy weather and applied "foreseeable" disturbances including cases of damage causing loss of watertight integrity. Also, this chapter and the corresponding explanation guide with its solutions presents the performance requirements 
Table 1. Environmental test conditions (ANEP-77, 2014)

\begin{tabular}{|c|c|c|c|c|c|c|c|c|c|}
\hline \multirow{3}{*}{ Service Class } & \multicolumn{3}{|c|}{ Operational } & \multicolumn{3}{|c|}{ Survival } & \multicolumn{3}{|c|}{ Damage } \\
\hline & \multicolumn{2}{|c|}{ Wind Speed } & \multirow{2}{*}{$\begin{array}{l}\text { Sig. } \\
\text { Wave } \\
\text { Height } \\
\text { (m) }\end{array}$} & \multicolumn{2}{|c|}{ Wind Speed } & \multirow{2}{*}{$\begin{array}{l}\text { Sig. } \\
\text { Wave } \\
\text { Height } \\
\text { (m) }\end{array}$} & \multicolumn{2}{|c|}{ Wind Speed } & \multirow{2}{*}{$\begin{array}{l}\text { Sig. } \\
\text { Wave } \\
\text { Height } \\
\text { (m) }\end{array}$} \\
\hline & $\begin{array}{l}\text { Nominal } \\
\text { (B*Fort) }\end{array}$ & $\begin{array}{l}\text { Design } \\
\text { (knots) }\end{array}$ & & $\begin{array}{l}\text { Nominal } \\
\text { (B*Fort) }\end{array}$ & $\begin{array}{l}\text { Design } \\
\text { (knots) }\end{array}$ & & $\begin{array}{l}\text { Nominal } \\
\left(B^{*} \text { Fort }\right)\end{array}$ & $\begin{array}{l}\text { Design } \\
\text { (knots) }\end{array}$ & \\
\hline Ocean Unlimited & 9 & 70 & 6.0 & 12 & 100 & 17.7 & 26 & 39 & 2.5 \\
\hline Ocean Limited & 8 & 60 & 6.0 & 10 & 80 & 11.2 & 26 & 39 & 2.5 \\
\hline Offshore & 7 & 50 & 4.0 & 8 & 60 & 6.2 & 24 & 36 & 2.2 \\
\hline Restricted Offshore & 6 & 40 & 2.5 & 7 & 50 & 4.3 & 22 & 33 & 1.8 \\
\hline Protected Waters & 5 & 30 & 1.25 & 6 & 40 & 2.5 & 20 & 30 & 1.5 \\
\hline Smooth Waters & 5 & 30 & 0.5 & 6 & 40 & 0.8 & 20 & 30 & 0.5 \\
\hline
\end{tabular}

and the verification methods about intact and damage stability (Pérez and Riola, 2011b).

This is the reason why this chapter is so important for the hydrodynamics model basin naval architects. To increase the safety of damaged ships, designers (Surko, 1994) focus more on damage mitigation than accident prevention. The damage mitigation requires prediction of the damage stability (Sarchin and Goldberg, 1962), the structural integrity, and the motion analysis for damaged ships in waves. Furthermore, pertinent ANEP-77 damage scenarios are developed to the damage safety criteria.

There are some notorious variations in the drafting of Regulation 2 (Watertight Integrity) and 3 (Reserve of Buoyancy) deleting the prescriptions related to maneuverability contained in order to create the new Regulation 5 (Maneuverability). But, without any doubt, the most remarkable change happened in Regulation 4 (Reserve of Stability) where only minor general requirements about stability were specified in 2009 Ed. of NSC and now in Ed. F a variety of several goals for the study of intact stability were chosen to be included by the people responsible of the project. The specialists' teams established a goal-based approach to the development of the code, developing each chapter in turn.

The basic principle of a goal-based approach is that the goals should represent the top tiers of the framework, against which a ship is verified both at design and construction stages, and during ship operation. This enables the ANEP-77 to become prescriptive if appropriate for the subject, or remains at a high level with reference to other standards and their assurance processes. The goal-based approach also permits innovation by allowing alternative arrangements to be justified as complying with higher-level requirements. The increasing width of the triangle as the ANEP-77 descends through the tiers implies an increasing level of detail (Riola and Pérez, 2009).

In ANEP-77, the goal based standards approach is anchored in five tiers outlined as follows:

- Tier 0 - Aim (philosophies and principles)

- Tier 1 - Goal

- Tier 2 - Functional areas

- Tier 3 - Performance requirements

- Tier 4-Verification methods

- Tier 5-Justification

Therefore, the goal-based approach provides a systematic framework for certification of a ship to meet the goals of ANEP-77. Performance requirements are defined based on the Concept of Operations (CONOPS) and verified using appropriate criteria. Although this approach contained in ANEP-77 provides for implementation of FSA approaches, it is not the same as an overarching design for safety approach in that ANEP-77 allows a Naval Administration to apply FSA in the Tier 4 verification of specific performance requirements associated with defined 
Fig. 4. NSC goal based approach (NSA, 2014)

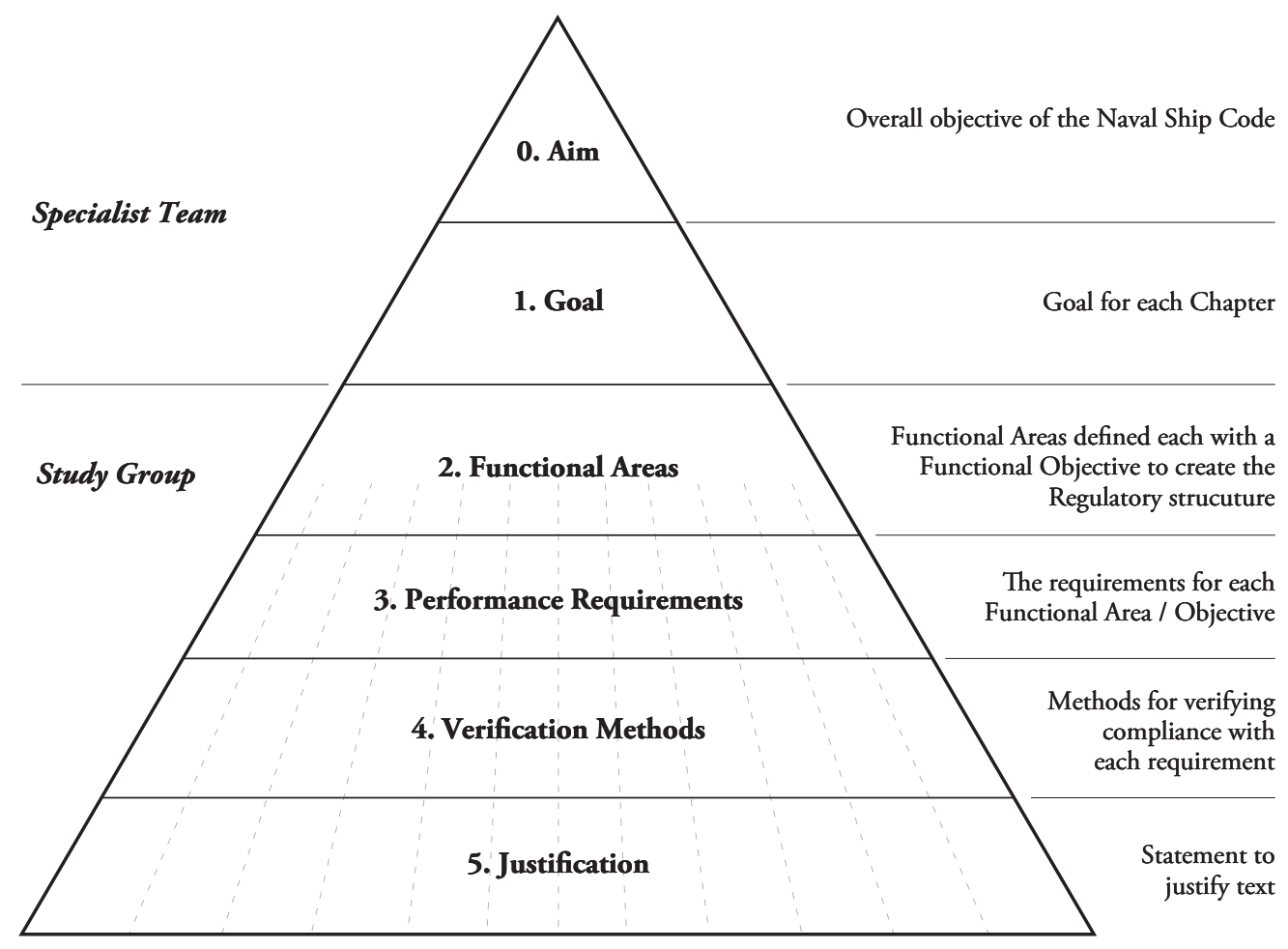

functional areas. Prescriptive standards can still be used to verify the goals (NATO, 2010).

\section{Naval Ships Damage Scenarios}

When a ship accident occurs because of several causes, both the hull and structures are damaged.
These damages cause the ship to flood, which can lead to sinking, capsizing or breaking up. The damage conditions used to predict the expansion of and loss due to damage are composed of a combination of the ship dimensions, sea states, and damage configurations, such as the location and extent of a damage hole. The ship dimensions can be represented by the loading conditions

Table 2. Summary table of damage categories (ANEP-77)

\begin{tabular}{|c|c|c|c|}
\hline & $\begin{array}{c}\text { Damage Category A } \\
\text { (DCA) }\end{array}$ & $\begin{array}{c}\text { Damage Category B } \\
\text { (DCB) }\end{array}$ & $\begin{array}{c}\text { Damage Category C } \\
\text { (DCC) }\end{array}$ \\
\hline Sphere & $1 \mathrm{~m}$ (radius) & $4 \mathrm{~m}$ (radius) & $10 \mathrm{~m}$ (radius) \\
\hline Cube & $2 \mathrm{~m}$ (edge) & $8 \mathrm{~m}$ (edge) & $20 \mathrm{~m}$ (edge) \\
\hline Horizontal prism & $\begin{array}{c}4 \mathrm{~m} \text { (length) } \\
0,5 \mathrm{~m} \text { (triangular edge) }\end{array}$ & $\begin{array}{c}16 \mathrm{~m} \text { (length) } \\
2 \mathrm{~m} \text { (triangular edge) }\end{array}$ & $\begin{array}{c}\text { 40m (length) } \\
5 \mathrm{~m} \text { (triangular edge) }\end{array}$ \\
\hline Vertical prism & $\begin{array}{c}4 \mathrm{~m} \text { (height) } \\
0,5 \mathrm{~m} \text { (triangular edge) }\end{array}$ & $\begin{array}{c}16 \mathrm{~m} \text { (height) } \\
2 \mathrm{~m} \text { (triangular edge) }\end{array}$ & $\begin{array}{c}\text { 40m (height) } \\
5 \mathrm{~m} \text { (triangular edge) }\end{array}$ \\
\hline Peak temperature & $100^{\circ} \mathrm{C}$ & $200^{\circ} \mathrm{C}$ & $300^{\circ} \mathrm{C}$ \\
\hline $\begin{array}{l}\text { Time to rise to peak } \\
\text { temperature }\end{array}$ & 5 minutes & 10 minutes & 20 minutes \\
\hline $\begin{array}{l}\text { Time for temperature to } \\
\text { revert to normal }\end{array}$ & 50 minutes & 100 minutes & 20 minutes \\
\hline
\end{tabular}


and geometrical characteristics such as the hull, length, breadth, draft, KG, and compartment arrangement, and the environmental conditions refer to wind and wave conditions such as height, length and period, and of course, the angle of the wave heading that has to be taking into account also.

The damage categories (Table 2), in ANEP-77, are based on defined shapes:

- Collision. To be used in the correct vertical orientation to describe the extent of collision damage from the bow of another ship, the apex representing the maximum penetration.

- Raking/grounding. To be used in the appropriate horizontal orientation to describe the extent of raking or grounding damage, the apex representing the maximum penetration.

- Cube. To be used to define the volume directly affected by fire and which may change in shape to fit the compartment.

- Sphere. To be used for explosions. For explosions detonating against the exterior of the hull, half the sphere to be used.

Collision: collision tests are done to every merchant ship meeting the SOLAS rules of the IMO. As it was mentioned in the introduction of this publication, warships are exempt from most of the laws of the merchant ships. This means that although collisions are not specifically damage related directly with the naval combat, warships shall be also tested to resist a collision situation. In ANEP-77, specifically in Chapter IX NAVIGATION, Regulation 9 Collision Avoidance, amendments to COLREGS (International Regulations for Preventing Collisions at Sea, 1972) from 2007 onwards have been incorporated/reviewed and included in this edition.

Grounding: it is not common to find a frigate sailing in swallow waters, considering the risks this represents, not so with littoral combat ships, amphibious ships or patrol boats. Grounding damage cases are described using the longitudinal location of the damage and the number of spaces affected. Using triangular prism shape specified on the ANEP-77 Code, the author can simulate which compartments of the ship have been affected by the accident. The damage extents are defined as the longitudinal damage length and width, which are determined by the ships speed, the thickness of the steel hull or structural details as transverse web spacing, and the underwater stone characteristics as height, hardness or toughness.

Weapons Damages: Fire and Explosions (cube and sphere cases): For naval ships, it is necessary to consider the damage of the attack caused by enemy weapons in addition to collision and grounding. At the moment, design rules for naval ships apply the criteria only to evaluate the adequate damage stability performance based on the righting arm curve but continuous research has focused on this area in recent years (Pérez and Riola, 2011a). Of course, it is impossible to predict the damage size, extension and location because it mainly depends on the success of the enemy weapon. As the ANEP-77 is to provide a level of safety appropriate to the role of the ship and benchmarked against statute while taking into account naval operations, it is necessary to define the degree of survivability in a way that can be taken into account in the development of the different chapters. As an example, the main

Fig. 5. Different damage shapes (ANEP-77, 2014)
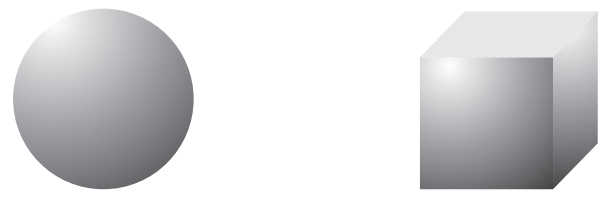

Sphere
Cube

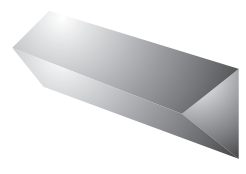

Raking/grounding

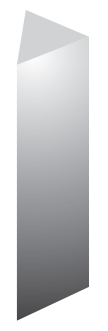

Collision 
difference between the fire safety approach from a naval and civilian shipping point of view is that SOLAS considers the risk of fire based on the function of each compartment whereas for naval ships, hostile acts may result in fire anywhere on the ship, both externally and internally.

Fig. 6. USS Stark (Weis, 1987)

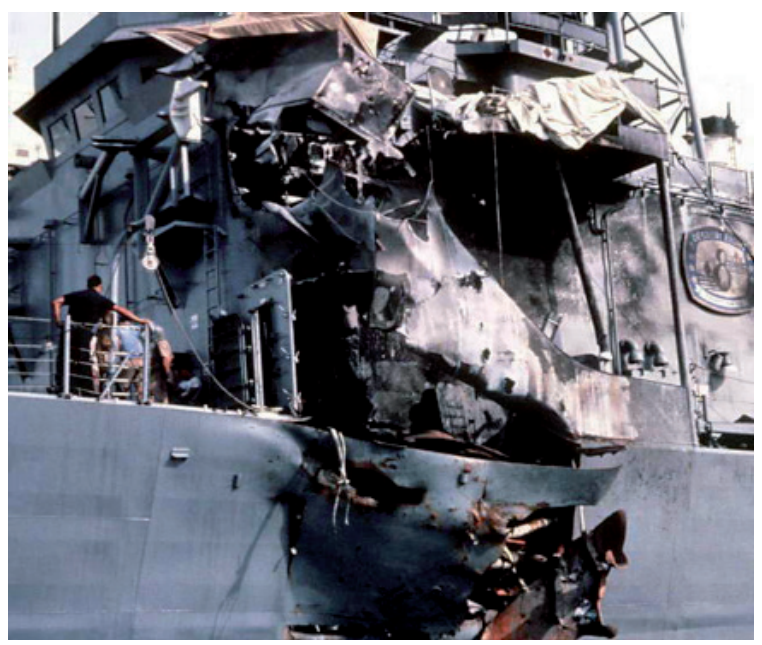

\section{Ship Dynamics Laboratory}

The future Frigates F-110 model tests can be carried out in the sea keeping basin of El Pardo Model Basin (CEHIPAR) close to Madrid. The basin has a sixty flaps wave maker, a computerized carriage (CPMC) and the following dimensions: 150 meters long x 30 meters width x 5 meters depth. IMO survivability tests, European Commission researches and the Stockholm Agreement supplement were carried out over recent decades, have provided widely recognized and experienced personnel in the maritime security field.

In order to reproduce the damage stability tests in the dynamic lab, a rigid scale model, a wave spectrum and a data acquisition system are necessary. The model should be as large as possible, since details of damaged compartments are easier constructed in larger models and the scale effects are reduced. It is therefore recommended that the model length is not less than that corresponding to a 1:40 scale. The data acquisition system consists mainly in an optical tracking system able to gatherthe information sent from the free model moving on the waves emitting light diodes. To maintain the same hydrostatic properties, a fiberglass model is built in a scale with the corresponding scale characteristics. It is required that the model is instrumented so that its roll, heave and pitch motions as well as its heel, sinkage and trim attitudes are monitored and recorded throughout the test. All the significant appendages such as rudders and keels are fitted and the inner damaged area compartmentation was made as realistic as possible. It is also important to ensure that the damaged compartments are modeled as accurately as practicably possible to ensure that the correct volume of floodwater is represented.

Fig. 7. Inner flooding compartments

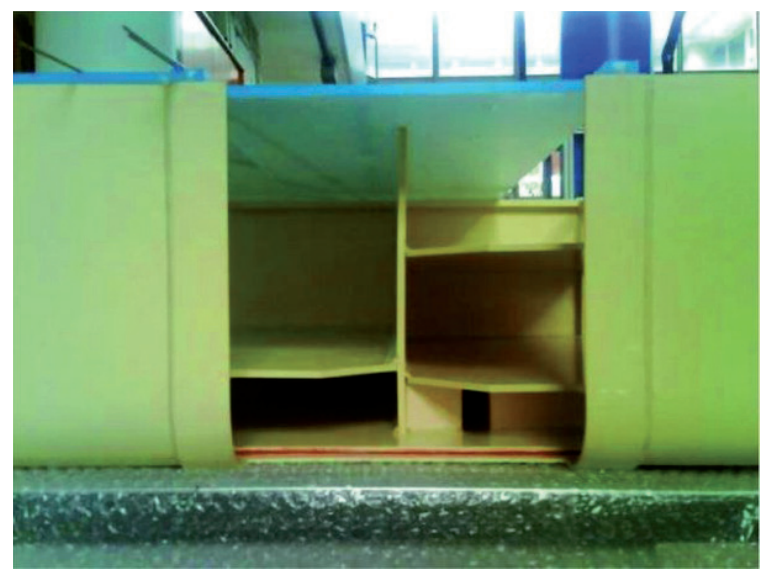

The model, considering the damages assumed, must be as thin as practically possible to ensure that the amount of flood water and its center of gravity is adequately represented. It is recognized that it may not be possible for the model hull and the elements of primary and secondary subdivision considering the damage to be constructed with sufficient detail and due to these constructional limitations it may not be possible to accurately calculate the assumed permeability of the space and the percentage of volume of the space, which may be occupied by seawater if the space is flooded. Typical values from the SOLAS are 0.95 for empty spaces, tanks, and living spaces, 0.85 for machinery spaces and 0.60 for spaces allocated to stores.

The vertical extent of the model can affect the results when tested dynamically, so it is 
required that the ship is modeled to at least three superstructure standard heights above the freeboard deck so that the large waves of the wave train do not break over the model. After measuring the damaged draughts it may be necessary to make adjustments to the permeability of the damaged compartment by either introducing intact volumes or by adding weights. This, to ensure that the model motion characteristics, the intact GM and the mass distribution are verified. The transverse radius of gyration of the actual ship is not to be taken as being greater than $0.4 \mathrm{~B}$ and the longitudinal radius of gyration is not to be taken as being more than 0.25L. The balance period will be defined as follows:

$$
T=\frac{2 \pi \cdot K}{\sqrt{g \cdot G M}}=\frac{2,006 \cdot K}{\sqrt{G M}}
$$

Where $K$ is the radius of inertia of the ship. It is normal to define this ratio as a beam function:

$$
T=\frac{f \cdot B}{\sqrt{G M}}
$$

$f$ values depend on the type, load case and general arrangement of the ship.

It is required that for every test run, the wave spectrum is recorded and documented. Measurements for this recording are to be taken in the immediate vicinity of the model and also near the wave maker machine. Extensive research carried out for the purpose of developing appropriate criteria for new vessels has clearly shown that in addition to the GM and freeboard being important parameters in the survivability of ships, the area under the residual stability curve up to the angle of maximum GZ is also another major factor. Consequently, in choosing the worst ANEP-77, damage for compliance with the requirement of the worst damage is to be taken as that which gives the least area under the residual stability curve up to the angle of the maximum GZ (Fig. 12).

\section{Dynamic Phenomena Basin Test}

Frigate design scale model will be verified in the following tests on the model basin: dynamic rolling, parametric excitation, resonant excitation, impact excitation, transient flooding, broaching, survivability test, etc. In order to define the boundary conditions of each test, the specifications of ANEP77 Environmental test conditions (refer Table 1) will be used, meeting the parameters of the three different conditions specified (Operational, Survival or Damage). Furthermore, the wave spectrum shall also be defined. Due to the severe characteristics, the survivability of warships model test in a basin must be tested with a Joint North Sea Wave Project (JONSWAP) wave spectrum. As an example, the transient flooding and survivability test has been chosen as the most representative, which will be explained in more detail in the next paragraphs.

Fig. 8. Parametric rolling test

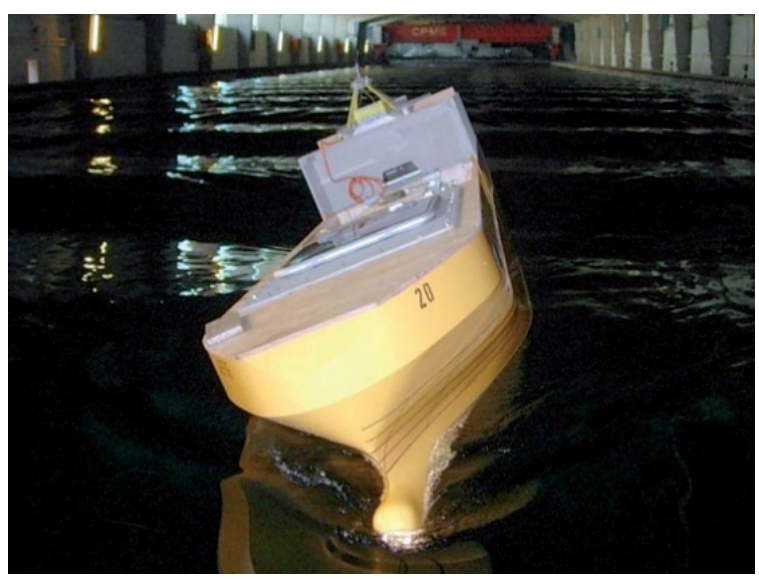

Warship naval architects admit that the naval ship survivability is one of the most attractive and important aspects in the preliminary phases of the naval project. Survivability is the enhanced ability of a ship to survive even in damaged conditions. Therefore, for new designs, the applicable stability and buoyancy standards must be integrated with the operational requirements. As it mentioned before, righting arms after damage curves are used to determine the adequacy of the ship's stability.

With the intention to get a good correlation between scale model and real ship, the following aspects shall be correctly defined:

- Definition of the compartments of the ship. Ships are provided with watertight subdivision to halt the flooding of water after damage and 
limit the spread of flooding. Increase the subdivision increases the ability to remain afloat.

- Definition of the permeability of each compartment.

- Design a good ventilation system of the model in order to avoid residual air chambers that could cause invalid results.

The model should be subjected to a long-crested irregular seaway as mentioned in the previous section (JONSWAP Spectrum) and should be free to drift and placed in beam seas with damage hole facing the oncoming waves. In 1968-1969 an extensive wave measurement program, known as the JONSWAP was carried out along a line extending over 100 miles into the North Sea from Sylt Island. From the analysis of the measurements, a spectral formulation of wind-generated seas with fetch limitation was found. The following definition of a Mean JONSWAP wave spectrum is recommended by the 15th International Towing Tank Conference (ITTC) in 1978 for fetch limited situation.

$$
\begin{aligned}
& S(w)=\frac{172,8 \cdot H_{1 / 3}^{2}}{T_{l}^{4}} \cdot w^{-5} . \\
& \exp \left\{\frac{-691,2}{T_{l}^{4}} \cdot w^{-4}\right\} \cdot A \cdot \gamma^{B} \\
& T_{l}=3,861 \cdot \sqrt{H_{1 / 3}} \\
& A=0,658 \\
& \gamma=3,3 \quad \text { (peakedness factor) } \\
& B=\exp \left\{-\left(\frac{\frac{w}{w_{p}}-1}{\sigma \sqrt{2}}\right)^{2}\right\} \\
& \sigma=\left\{\begin{array}{ll}
0,07 & w<w_{p} \\
0,09 & w>w_{p}
\end{array}\right\} \\
& w_{p}=\frac{2 \pi}{T_{p}}
\end{aligned}
$$

Fig. 9. Damage stability test at CEHIPAR (2006)

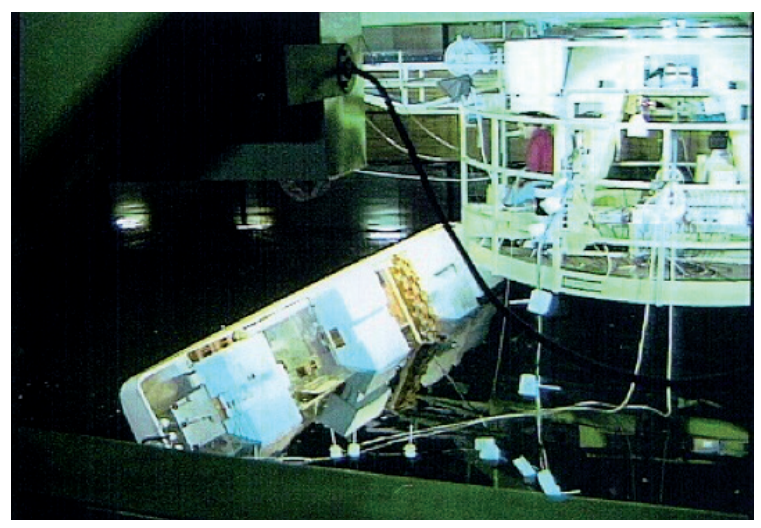

\section{Transient Flooding Test}

After a collision produced by another ship or an explosion produced by an enemy weapon, a sudden ingress of water could happen, inducing a fast increase of heeling moment, at least, in the damaged lateral tanks, this generates a large roll motion of the vessel. If the heel is enough to permit additional flooding, the heeling moment may exceed the residual restoring moment, which results in the capsizing of the vessel.

For ship motion simulation with sudden water ingress and waves, Cummins is the most appropriated to simulate the phenomenon:

$$
\begin{aligned}
\sum_{j=1}^{h} & \left\{\left(M_{i, j}+A_{i, j}\right) \ddot{x}_{j}(t)\right. \\
& \left.\quad+\int_{0}^{\infty} B_{i, j}(\tau) x_{j}(t-\tau) d \tau+C_{i, j} x_{j}(t)\right\}=X_{i}(t)
\end{aligned}
$$

Weather conditions are important factors in a survival condition after damage. The proper method to test a scale model is based on beam seas with the damage facing the wave direction. Damage extension provides damage categories $(A, B$ or $C)$ specified in ANEP-77, residual freeboard and metacentric heights, which are the main parameters with influence in the ingress of water and the ship roll response. This test allows simulating the hydrodynamic behavior of the future ship in the event of damages in her hull. It is very important in 
Fig. 10. Transient flooding test dynamic response (Riola and Valle, 2001)

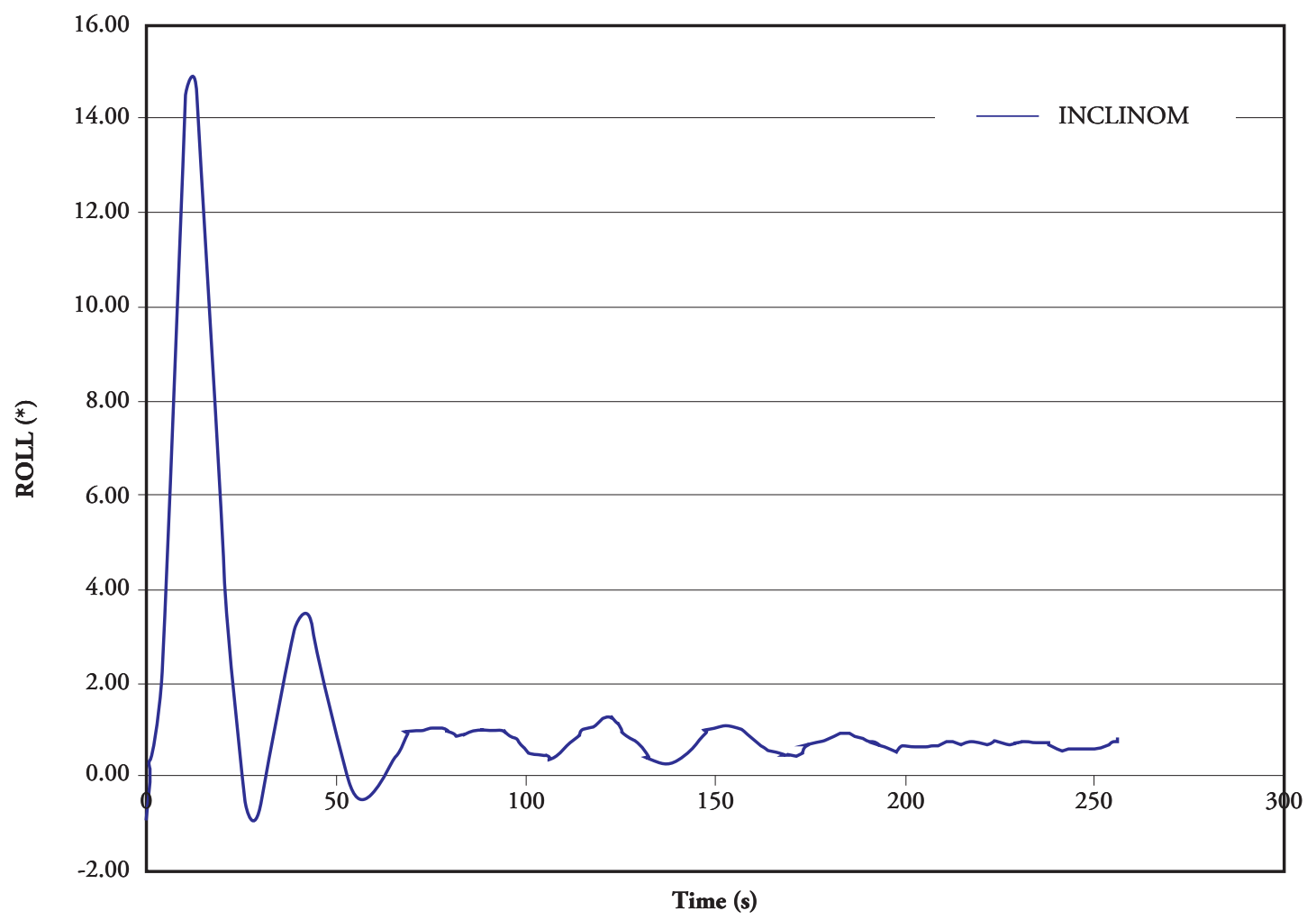

warships because they operate under hostile threats during their missions.

\section{SICP System on F-110 Frigates}

\section{Class}

SICP is the Spanish acronym for Integrated Control Platform System. The main mission of the SICP is to provide up-to-date, reliable and well- structured information to SICP operators with the ultimate goal of reducing staff members dedicated to monitoring and controlling the platform, as well as to increase access to coherent and complete information on the status of the platform to the ship's command personnel.

Thanks to the design of the SICP, its operators are always fully aware of the state of the subsystems of the platform. All of these capabilities make the

Fig. 11. Survivability test and scheme of the results (Riola, 2001)
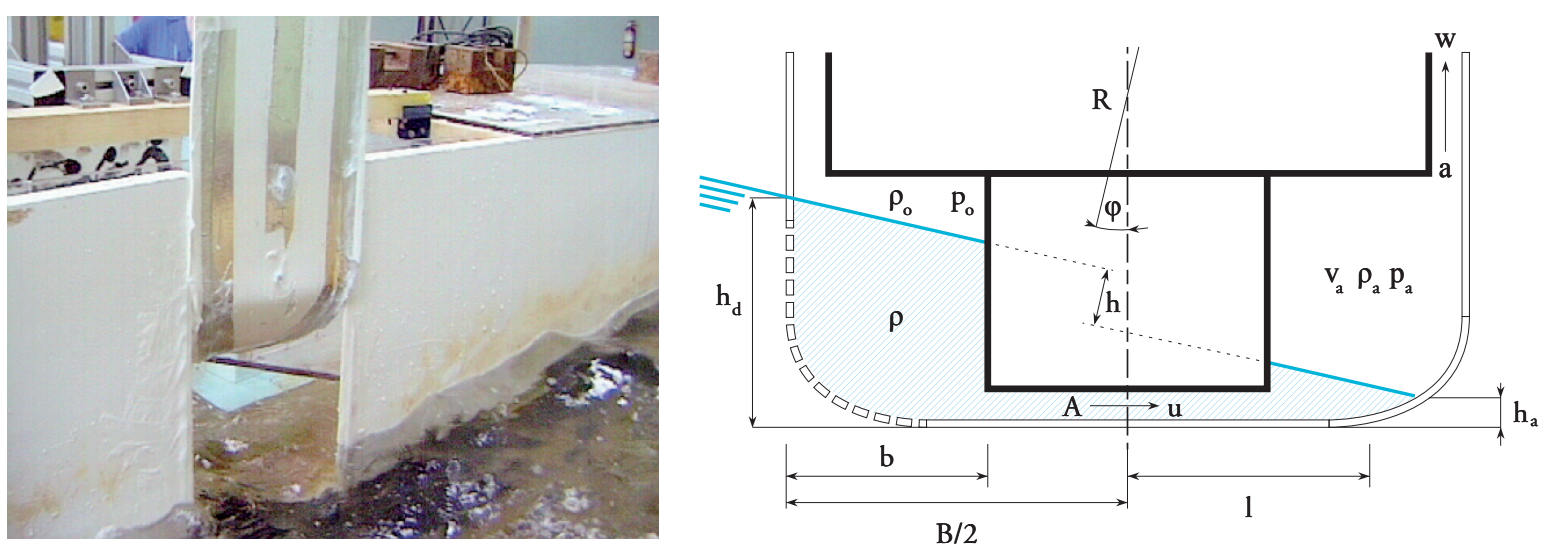
implementation and use of the SICP increase the on board safety of the ship. The SICP increases the predictive maintenance capacity by controlling and monitoring a large number of platform elements. Every parameter related with the stability tests made to the model shall be included in the SICP system in order to help in the controllability and maneuverability of the ship.

\section{Conclusions}

- The ANEP-77 has become the criterion of stability in damage that most closely resembles the standards of the navy in the 21st century, as it has been reflected throughout the paper.

- We have proposed an extensive explanation of the ANEP-77 stability after the damage criteria. There are many areas where military vessels could improve safety standards, although not necessarily to be regarded as less secure than the civil vessels. However, there are major difficulties in implementing all the rules of the Classification Societies in the naval field, especially to establish a priority mission and capacity combat against security. It is remarkable to distinguish the importance of the new ANEP-77 rules about dynamic ship phenomena, especially in damage tests.

- For the effective application of the ANEP77 , it is necessary to clearly define the extent of the damage that reflects the potential damage caused by hostile acts, the damage location, degree of vulnerability, hull and superstructure protection, systems redundancy, materials, the post-damage ship capability and the philosophy for recovery from the damaged state.

- Hydrodynamics Studies on damage safety aim to make F-110 frigates safer on an ongoing basis, in particular, there are many outstanding

Fig. 12. GZ comparison damages simulation for a 6.000 tons frigate (Riola, de la Puente and Gómez, 2016)

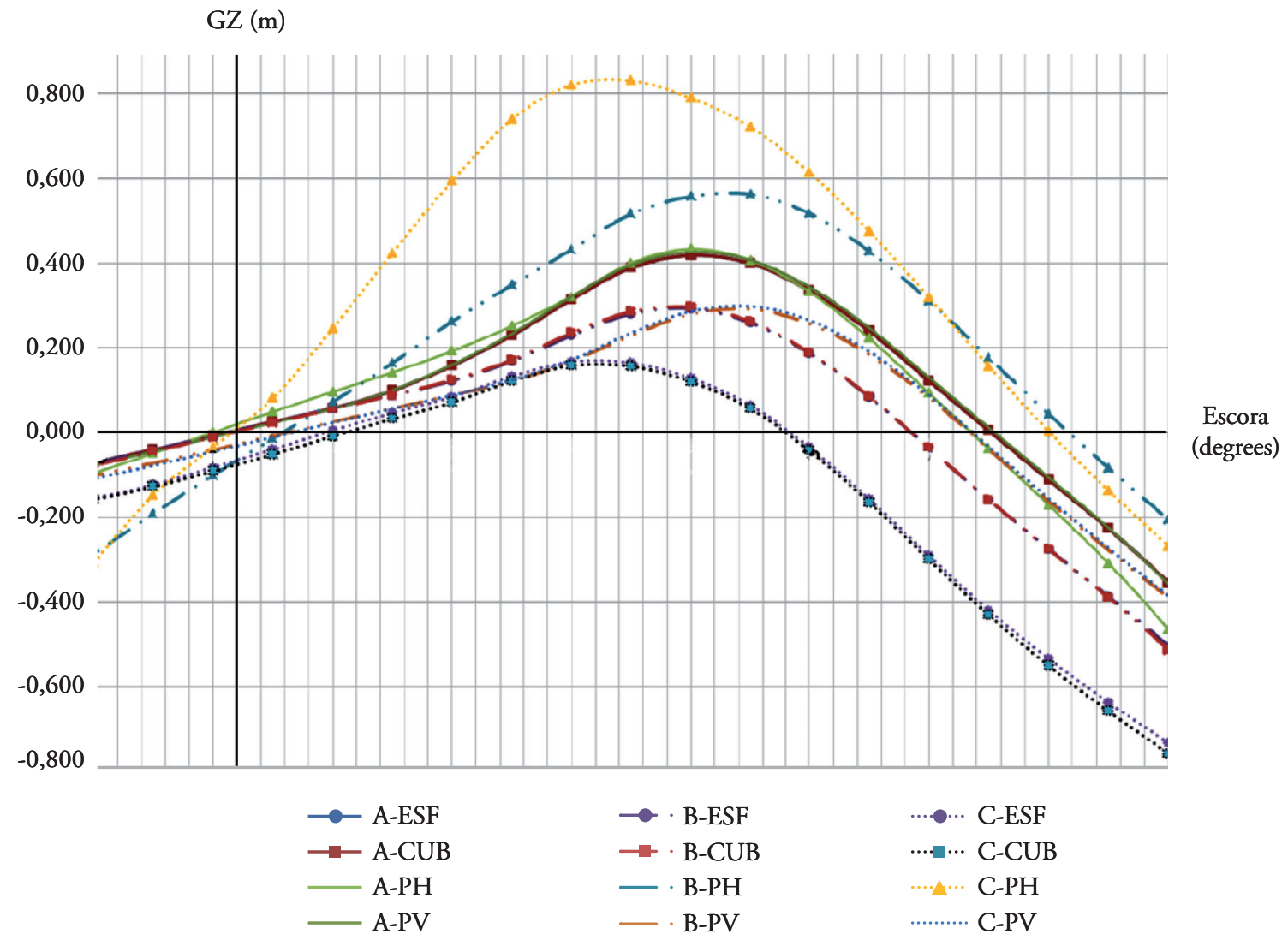


descriptions, formulas, and technical procedures on this stability paper that shows factors that can be used to develop damage scenarios for collision, grounding, and attack accidents. Damage safety assessment is not only required in the design phase but can also be applied in the operation phase that should guarantee high rapid response and useful information to the decision makers in emergencies.

- The F-110 frigate class represents a critical program into the Spanish Navy strategic goals. Before initiating the execution phase, model basin test shall be carried out to improve the capabilities of the ship. As we are actually checking at CEHIPAR, dynamic stability tests are the most critical. Damage survivability tests are a fundamental database for the future frigate behavior in operations. The data obtained from the basin tests have an enormous value for future behavior of the SICP response for the comfort of the crew in normal sailing conditions and specially, during the fast response under emergency situations.

\section{Bibliographic References}

NATO Standardization Agency (NSA), Naval Ship Code. Allied Naval Engineering Publication, August 2014, ANEP-77, Ed. F, ver.1. Brussels:

Marina Militare Italiana, Available: https://marina. difesa.it

Pérez, R. and Riola, J.M., "Case study of damage stability criteria of Merchant vessels and Warships", Damaged Ship International Conference. 26-27 January 2011. London, UK.

Pérez, R. and Riola J.M., "Damage Stability Criteria in Aircraft Carriers," in Journal of Marine
Technology and Environment, Vol. 1, 2011, pp. 27-38.

Riola, J.M., "Estudio dinámico de la supervivencia en la mar de buques ferries con avería. Altura de agua sobre la cubiertadel garaje e influencia de la superestructura," Phd thesis UPM, 2001, Madrid.

Riola, J.M. and Perez, R., "Warship damage stability criteria case study," in Journal of Maritime Research, 6(3), 2009, pp.75-100.

Riola. J.M. and Valle, J., "Transient flooding in a damaged ferry," PRADS 2001, 2001, Shanghai, China.

US Navy, Naval Ship Engineering Center, Design Data Sheet-Stability and Buoyancy of US Naval Surface Ships. DDS 079-1. US Navy, currently Naval Sea Systems Command, 1975, Washington, USA.

Riola, J.M., De la Puente, J., Gómez, F., "Cambios en la normativa de Estabilidad Militar," $55^{\circ}$ Congreso de Ingeniería Naval e Industria Marítima, 2016.

Riola J.M., Pérez-Villalonga, F.J., "Naval Ship Code, Una nueva normativa internacional para buques de Guerra," in Revista General de Marina, June 2008.

Sarchin, T.H. and Goldberg, L.L., "Stability and buoyancy criteria for the U.S. naval surface ships. Trans," SNAME. Vol. 70, 1962, 418-458.

Surko, S.W., "An assessment of current warship damaged stability criteria," in Naval Engineers Journal, Vol. 106, № 2, 1994, pp. 120-131.

Weiss, F., USS STARK, Photogrphic History of US Navy: NavSource. Available: www.navsource. org 